\title{
The historical glazed tiles from Nossa Senhora da Soledade Cemetery, Northern Brazil: microstructural, physical and mineralogical characterization
}

\section{(Azulejos históricos do Cemitério Nossa Senhora da Soledade, Norte do Brasil: caracterização microestrutural, física e mineralógica)}

\author{
S.A.M. Gasparetto*, T.A.B.C.Sanjad \\ Laboratório de Restauração, Conservação e Reabilitação, Programa de Pós-Graduação em Arquitetura e \\ Urbanismo, Universidade Federal do Pará, Av. Augusto Correa 1, Belém, PA, Brasil 66075-110
}

\begin{abstract}
During the nineteenth century, historical glazed tiles were used in the mortuary architecture of Nossa Senhora da Soledade Cemetery, in Belém. These ceramic pieces are an extraordinary part of Brazilian cultural heritage but are at a high deterioration stage due to conditions to which they are subjected. The aim of this research was the microstructural, physical and mineralogical characterization of glazed tiles from Nossa Senhora da Soledade Cemetery. The samples consisted of Portuguese fragments from the nineteenth century, decorated by stamping. The characterization was performed by optical microscopy, scanning electron microscopy with energy dispersive spectroscopy, water absorption test, and X-ray diffractometry. The results indicated that glazed and ceramic layers have manufacturing defects and a heterogeneous character due to the handmade production process. The porosities vary from $13.3 \%$ to $22.9 \%$. The ceramics are composed of quartz, gehlenite, calcite, rutile, cristobalite, diopside, anorthite, hematite and wollastonite. According to the results, despite many similarities (country of origin, century of production, decorative technique), the samples have variations in their microstructure and mineralogy. Information regarding the compositions of the tiles and their variation is important to support future restorative interventions.
\end{abstract}

Keywords: historical glazed tiles, mortuary architecture, microstructure, mineralogy.

Resumo

Durante o século XIX em Belém-PA, destaca-se o uso da azulejaria na arquitetura mortuária do Cemitério Nossa Senhora da Soledade. Estes azulejos são extraordinários componentes do patrimônio azulejar brasileiro, mas encontram-se em elevado estágio de deterioração, devido às condições a que estão submetidos. Esta pesquisa objetivou a caracterização microestrutural, fisica e mineralógica de azulejos das sepulturas do Cemitério Nossa Senhora da Soledade. A amostragem consistiu em fragmentos portugueses do século XIX, decorados em estampilha. A caracterização foi realizada por microscopia óptica, microscopia eletrônica de varredura com espectroscopia de energia dispersiva, teste de absorção total em água e difratometria de raios X. Os resultados indicaram que as camadas vitrificadas e cerâmicas possuem caráter heterogêneo e defeitos de fabricação, devido ao processo de produção artesanal. As porosidades variam de 13,3\% a 22,9\%. As chacotas apresentam em sua composição: quartzo, gehlenita, calcita, rutilo, cristobalita, diopsídio, anortita, hematita e wollastonita. De acordo com os resultados, apesar de possuírem em comum o país de origem, século de produção, técnica decorativa e temperatura de queima, as amostras apresentam variações em sua microestrutura e mineralogia. Tais informações são importantes para o conhecimento do material para fundamentar futuras intervenções restaurativas.

Palavras-chave: azulejo, arquitetura mortuária, microestrutura, caracterização mineralógica.

\section{INTRODUCTION}

The use of glazed tiles (azulejos) in Brazil is strongly linked to the country's metropolis-colony relations with Portugal. Although older specimens exist, the peak of use of the tiles in Belém took place in the nineteenth century during the rubber economic period, when European materials were frequently imported. The sanitation policy and urban beautification during the Belle Époque led to the large-scale use of tiles as coating for the external façades of city buildings [1]. Due to this context, a variety of patterns, styles and decorative techniques, derived mainly from Portugal, Germany and France, are observed in Belém.
Also, in this period, the use of tiles in mortuary architecture of Nossa Senhora da Soledade stands out (Fig. 1). The Nossa Senhora da Soledade Cemetery was built in 1850, following the style of European romantic cemeteries, with an organic landscaping and a great variety of sculptures and mausoleums. The Cemetery is protected on a national level by the Brazilian National Historic and Artistic Heritage Institute (IPHAN). It is an important historical and artistic expression from the nineteenth century and is one of the only three monumental cemeteries in Brazil, jointly with the cemeteries of Consolação (São Paulo) and Campo Santo (Salvador).

The historical tiles of the graves are an extraordinary part 


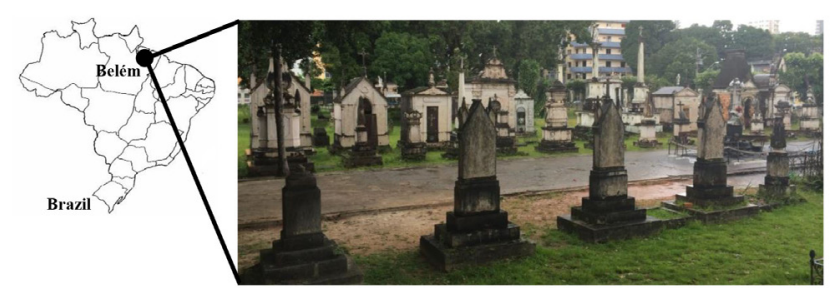

Figure 1: Location of Belém in the map of Brazil and a recent photograph of Cemetery Nossa Senhora da Soledade.

[Figura 1: Localização de Belém no mapa do Brasil e uma fotografia recente do Cemitério Nossa Senhora da Soledade.]

of the Brazilian cultural heritage mostly because of three factors. The first is the fact that they were applied during a period when the use of tiles as artistic support in cemetery structures was still rare. In the Romantic period, the stonework techniques for ornamentation of the monumental graves stand out [2]. The second factor is because these tiles are Portuguese standards of the nineteenth century, decorated with stamping technique, with colorful patterns, characteristic of building façades. This practice was considered different, because the use of tiles with funeral symbolism was the most common. The last reason is that most of the grave tiles are unusual or inexistent in other areas of the city. Nonetheless, the high stage of deterioration of these material results in large losses as a consequence of weather conditions, and there are no studies related to these materials. These alterations are further accelerated by the proximity of the pieces to the ground and by human action, that is, the burning of the candles during religious services. The aim of this research was the microstructural, physical and mineralogical characterization of glazed tiles from the graves located at the Nossa Senhora da Soledade Cemetery, for documentation purposes and knowledge of the material to support future restorative interventions.

\section{MATERIALS AND METHODS}

Sampling: consisted of fragments of ancient Portuguese tiles, decorated with the stamping technique, collected from eight different graves of Nossa Senhora da Soledade Cemetery (Figs. 2 and 3). The acquisition of samples was authorized by IPHAN, and the samples were taken from areas where extraction could be easy, in which the pieces were already fractured and had weak adhesion to the support, in an effort to preserve the artistic unity of the graves and avoid new damage.

Laboratorialanalysis: theimages for micromorphological characterization of ceramic layers and glazed tiles were obtained by an optical microscope (Axio Lab.1, Carl Zeiss), with Axiocam camera, and scanning electron microscopy with energy dispersive spectroscopy (SEM/EDS, LEO, 1430VP). The samples were inserted in polyester resin for analysis in the section areas. They were polished (Politriz PLF, Fortel), with the usage of sandpaper of different grain sizes (120, 200, 400, 600 and 1200 grade). Furthermore, for the SEM/EDS analysis, the samples were metalized with

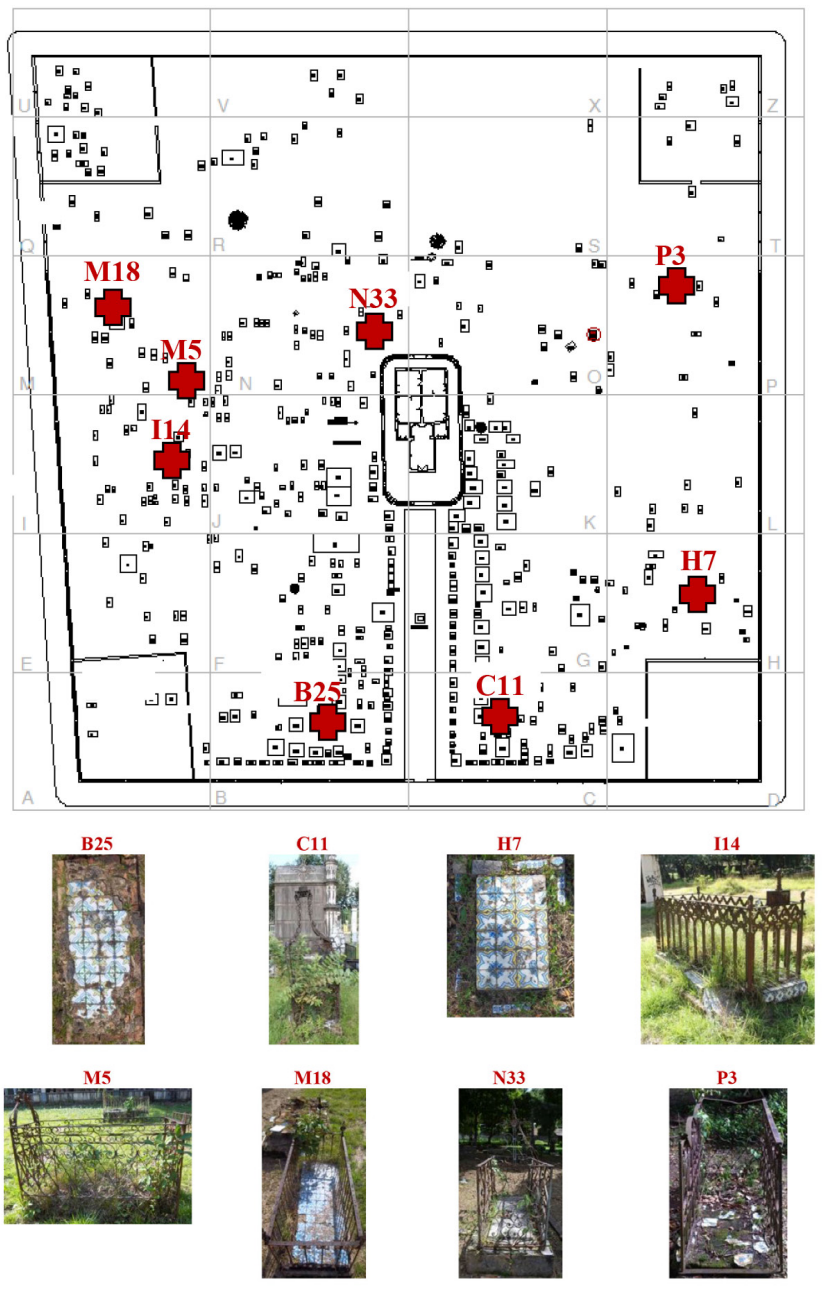

Figure 2: Plan of the Soledade Cemetery with marking of tiled graves selected for research. Source: elaborated from a map of the IPHAN cadastral base.

[Figura 2: Planta do Cemitério Soledade com marcação de túmulos selecionados para pesquisa. Fonte: elaborado a partir de um mapa da base cadastral do IPHAN.]
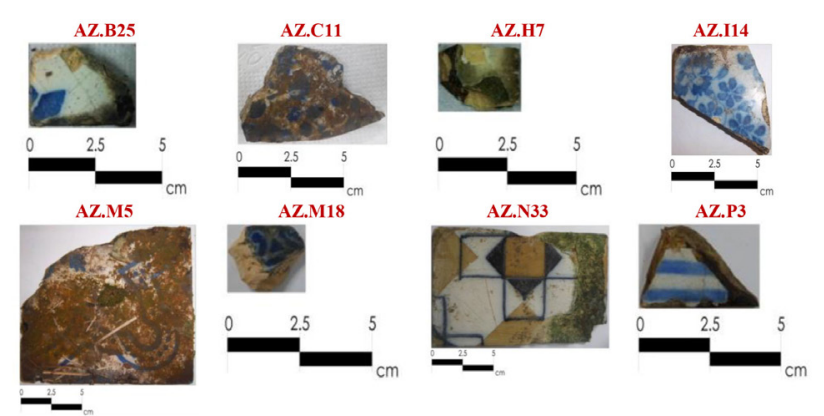

Figure 3: Samples: fragments of tiles used in research.

[Figura 3: Amostras: fragmentos de azulejos usados na pesquisa.]

gold (Emilech K550X Auto Fine Coater). The observed variables were thickness of the glaze, texture of the ceramic, interface zone between the two layers, characteristics of the matrix and existing grains in the ceramic and in the glaze, manufacturing defects, and alterations caused by weathering, like fissures, fractures and deterioration processes in the 
material. In order to verify accessible porosity of the ceramic material, the physical characterization of fragments was performed by water absorption test, following the procedure by the standard ABNT NBR 15845 [3]. The mineralogical composition of the tiles was determined by powder X-ray diffraction analysis, using a diffractometer (PANalytical X'Pert PRO MPD, PW3040/60, $\theta / \theta$ ) with a ceramic X-ray tube $\left(\mathrm{Cu}\right.$ anode, $\left.\mathrm{K} \alpha_{1}=1.540598 \AA\right), \mathrm{Kb}$ Ni filter, and an $\mathrm{X}$ 'celerator PSD (position-sensitive detector). Instrumental conditions used were as follows: scan range from 5 to $100^{\circ}$, tube power of $40 \mathrm{kV}$ and $30 \mathrm{~mA}$, step size of $0.02^{\circ}$, time/ step of $60 \mathrm{~s}$, divergence slit of $1 / 8^{\circ}$, anti-scattering slit of $1 / 4^{\circ}$, mask of $10 \mathrm{~mm}$, and sample spinning with a rotation time of $1.0 \mathrm{~s}$.

\section{RESULTS}

Physical and micromorphological characteristics. Glazed layer: the glazed layers were generally thick and varied between $0.20 \mathrm{~mm}$ and $0.66 \mathrm{~mm}$. They had discontinuities, with grains and encrustations immersed in a vitreous matrix, in which were identified the presence of $\mathrm{SiO}_{2}, \mathrm{PbO}, \mathrm{Al}_{2} \mathrm{O}_{3}, \mathrm{CaO}, \mathrm{K}_{2} \mathrm{O}, \mathrm{Na}_{2} \mathrm{O}$ and $\mathrm{MgO}$, as well

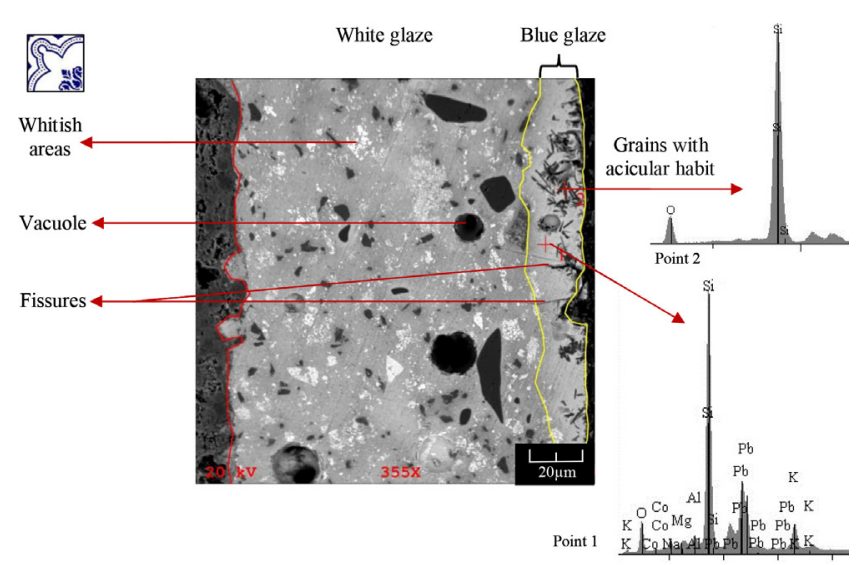

Figure 4: SEM micrograph of the glazed layer of sample AZ.M5 (Group 2), with EDS analytical spectra.

[Figura 4: Micrografia obtida por microscopia eletrônica de varredura do vidrado da amostra AZ.M5 (Grupo 2), com espectros de EDS.]

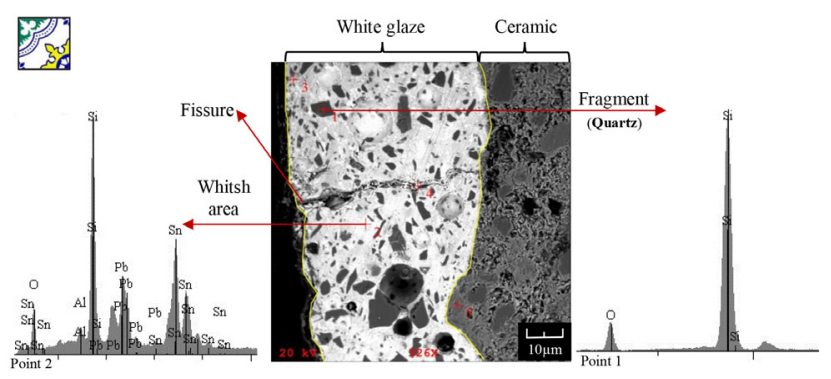

Figure 5: SEM micrograph of the glazed layer of sample AZ.B25 (Group 1), with EDS analytical spectra.

[Figura 5: Micrografia obtida por microscopia eletrônica de varredura do vidrado da amostra AZ.B25 (Grupo 1), com espectros de EDS.]

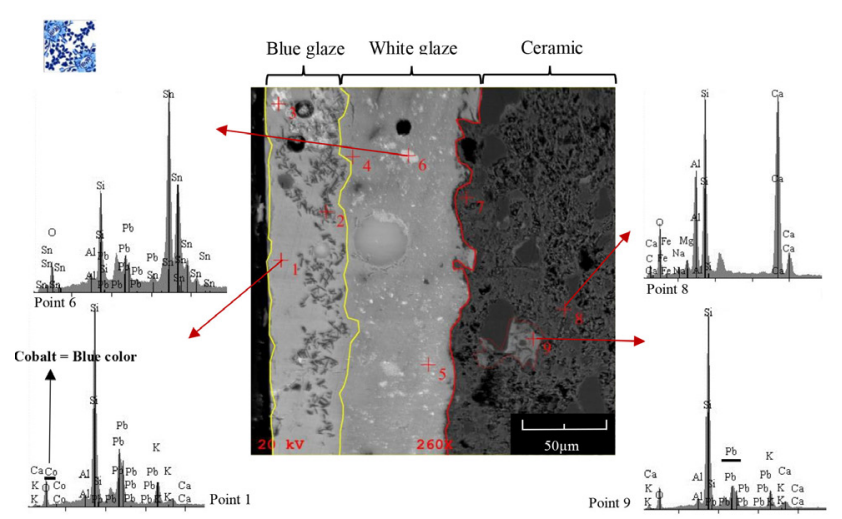

Figure 6: SEM micrograph of glazed layer of the sample AZ.C11 (Group 2), with EDS analytical spectra.

[Figura 6: Micrografia obtida por microscopia eletrônica de varredura do vidrado da amostra AZ.C11 (Grupo 2), com espectros de EDS.]
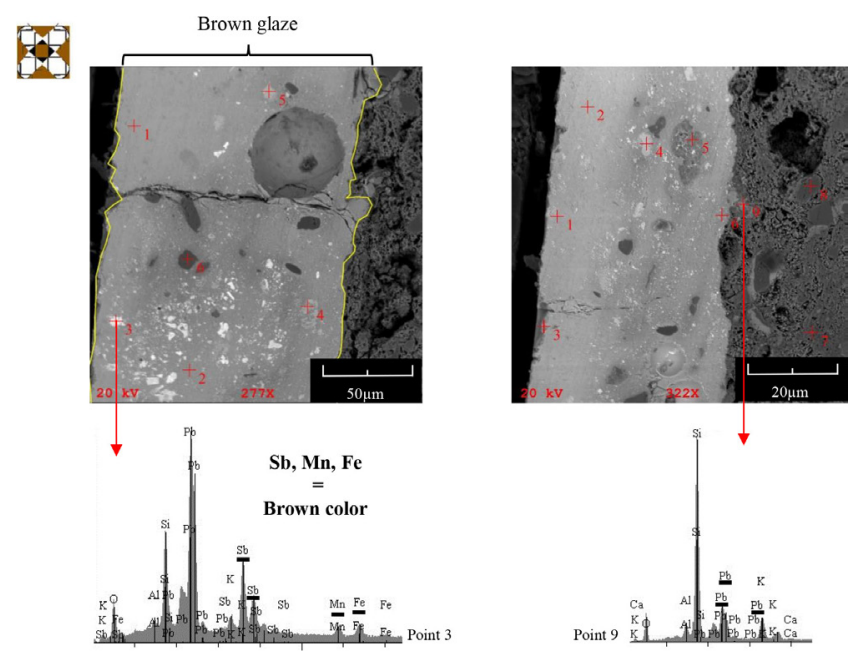

Figure 7: SEM micrographs of glazed layer of the sample AZ.N33 (Group 2), with EDS analytical spectra.

[Figura 7: Micrografias obtida por microscopia eletrônica de varredura do vidrado da amostra AZ.N33 (Grupo 2), com espectros de EDS.]

as manufacturing defects, such as vacuoles (formed by air bubbles released during the firing process), fissures and microcracks with different extensions and thicknesses (Fig. 4). Based on these aspects, it was possible to divide the tiles into two groups. The first group was formed by samples AZ.B25, AZ.H7 and AZ.M18 (Group 1). In these tiles, the white glaze had a higher concentration of vacuoles and two kinds of fragments: 1) with a sub-rounded shape, consisting mainly of $\mathrm{SiO}_{2}$; 2) with light shades (whitish areas), consisting mainly of $\mathrm{SnO}$ (Fig. 5). The second group covered samples AZ.N33, AZ.C11, AZ.I14, AZ.M5 and AZ.P3 (Group 2). In this group, the white glaze had a more homogeneous form, with fewer vacuoles, but some white agglomerations of $\mathrm{SnO}$ (Figs. 4 and 6). It was also possible to observe peculiarities in the blue glaze of samples AZ.C11 and AZ.M5, which contained $\mathrm{SiO}_{2}$ grains with an acicular shape (Fig. 4). Some chromophore elements were also 
identified in the analyzed pieces, such as $\mathrm{CoO}$, in the blue glazes of samples AZ.M5 and AZ.C11 (Fig. 4 and Fig. 6), and $\mathrm{Fe}_{2} \mathrm{O}_{3}, \mathrm{MnO}$ and $\mathrm{Sb}_{2} \mathrm{O}_{3}$ in the brown glaze of sample AZ.N33 (Fig. 7).

Ceramic layer: the ceramic layers had a yellowish tone and heterogeneous nature, with voids and $\mathrm{SiO}_{2}$ particles in different sizes (Fig. 8), which were surrounded by a thin and porous matrix composed by $\mathrm{SiO}_{2}, \mathrm{Al}_{2} \mathrm{O}_{3}, \mathrm{CaO}, \mathrm{Fe}_{2} \mathrm{O}_{3}, \mathrm{MgO}$, $\mathrm{Na}_{2} \mathrm{O}$ and $\mathrm{K}_{2} \mathrm{O}$ (Figs. 6 and 8). $\mathrm{PbO}$ was also identified in samples AZ.C11 and AZ.N33. In the first case, $\mathrm{Pb}$ was located in the middle of the ceramic layer (Fig. 6), and in the second in the interface zone between the glazed and ceramic layers (Fig. 7). The results of the water absorption test varied from $13.3 \%$ in sample AZ.C11 to $22.9 \%$ in sample AZ.I14 (Table I).

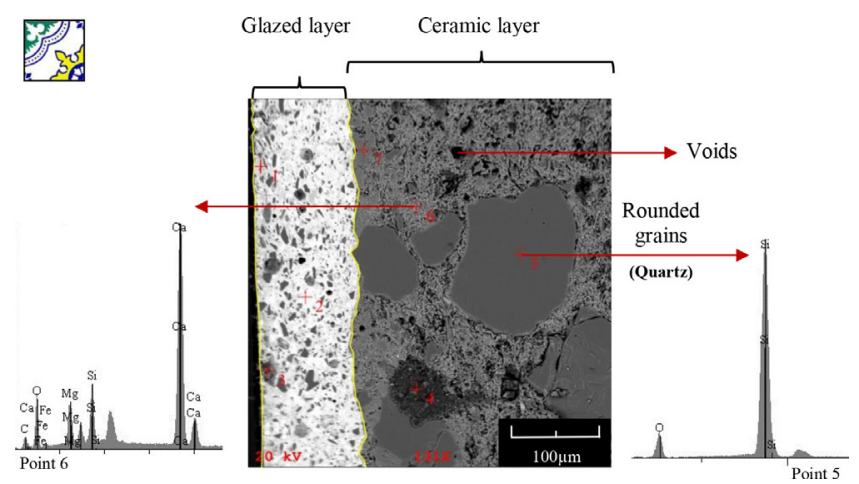

Figure 8: SEM micrograph of ceramic layer of the sample AZ.B25, with EDS analytical spectra.

[Figura 8: Micrografia obtida por microscopia eletrônica de varredura da cerâmica da amostra AZ.B25, com espectros de EDS.]

Alterations: the recurrence of superficial problems, which do not compromise the material (as deposits and soiling), and alterations derived from manufacturing defects were verified. An example of the latter is fissures in the glaze, from microcrack extension that led to changes in the ceramic material (Fig. 9) or loss of the glaze.

Mineralogical composition of ceramic layer: the mineralogical composition of the analyzed Portuguese tiles consisted primarily of quartz $\left(\mathrm{SiO}_{2}\right)$ and gehlenite $\left[\mathrm{Ca}_{2} \mathrm{Al}(\mathrm{SiAl}) \mathrm{O}_{7}\right]$, containing also, in different samples, calcite $\left(\mathrm{CaCO}_{3}\right)$, rutile $\left(\mathrm{TiO}_{2}\right)$, cristobalite $\left(\mathrm{SiO}_{2}\right)$, diopside $\left(\mathrm{CaMgSi}_{2} \mathrm{O}_{6}\right)$, anorthite $\left(\mathrm{CaAl}_{2} \mathrm{Si}_{2} \mathrm{O}_{8}\right)$, hematite $\left(\mathrm{Fe}_{2} \mathrm{O}_{3}\right)$, and

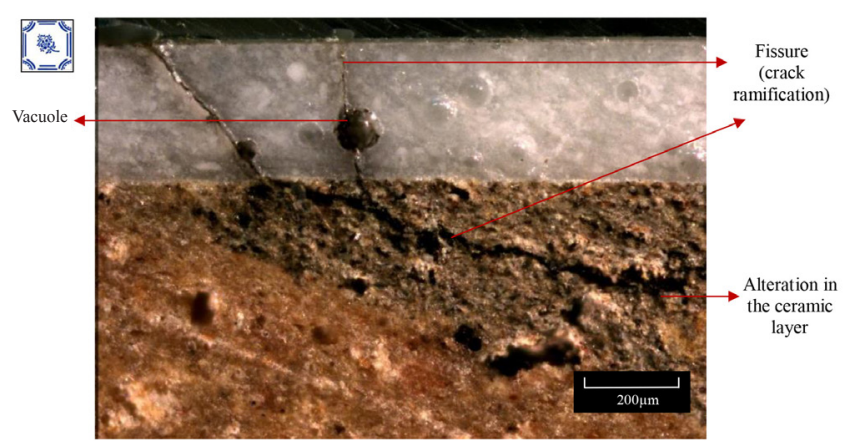

Figure 9: Optical micrograph of sample AZ.P3.

[Figura 9: Micrografia óptica da amostra AZ.P3.]

Table II - Mineralogical composition of ceramic layers. [Tabela II - Composição mineralógica das cerâmicas.]

\begin{tabular}{|c|c|c|}
\hline \multicolumn{2}{|c|}{ Sample } & Mineralogy \\
\hline B25 & & $\begin{array}{l}\text { Quartz, gehlenite, calcite, } \\
\text { rutile }\end{array}$ \\
\hline $\mathrm{C} 11$ & & $\begin{array}{l}\text { Quartz, gehlenite, calcite, } \\
\text { cristobalite, hematite, } \\
\text { wollastonite }\end{array}$ \\
\hline $\mathrm{H} 7$ & & $\begin{array}{l}\text { Quartz, gehlenite, } \\
\text { wollastonite }\end{array}$ \\
\hline $\mathrm{I} 14$ & & $\begin{array}{l}\text { Quartz, gehlenite, calcite, } \\
\text { anorthite, diopside }\end{array}$ \\
\hline M5 & & $\begin{array}{l}\text { Quartz, gehlenite, calcite, } \\
\text { wollastonite }\end{array}$ \\
\hline M18 & & $\begin{array}{l}\text { Quartz, gehlenite, hematite, } \\
\text { diopside }\end{array}$ \\
\hline N33 & & Quartz, gehlenite, hematite \\
\hline P3 & & $\begin{array}{l}\text { Quartz, gehlenite, calcite, } \\
\text { cristobalite, diopside }\end{array}$ \\
\hline
\end{tabular}

wollastonite $\left(\mathrm{CaSiO}_{3}\right)$ (Table II). The tiles were divided into two major groups, according to the carbonates existent in the raw material used in the ceramics pastes: 1) ceramics with minerals originated from Ca-rich clays, composed by samples AZ.B25 and AZ.N33, which had only the presence of gehlenite (Group 1.A), and samples AZ.C11, AZ.H7 and AZ.M5, which had in common the presence of gehlenite

Table I - Results of the total water absorption test.

[Tabela I - Resultados do ensaio de absorção de água.]

\begin{tabular}{|c|c|c|c|c|c|c|c|c|}
\hline Sample & $\begin{array}{l}\text { B25 } \\
0 \\
0\end{array}$ & 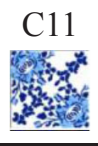 & H7 & 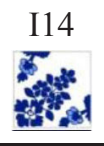 & $\begin{array}{l}\text { M5 } \\
\text { sis }\end{array}$ & $\begin{array}{r}\text { M18 } \\
\\
\end{array}$ & $\begin{array}{l}\text { N33 } \\
4 \\
\end{array}$ & 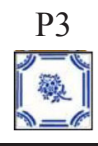 \\
\hline Dry mass $(\mathrm{g})$ & 16.81 & 37.16 & 7.65 & 9.24 & 77.18 & 5.55 & 67.70 & 2.63 \\
\hline Wet mass (g) & 19.78 & 42.10 & 8.84 & 11.36 & 89.44 & 6.68 & 82.65 & 3.15 \\
\hline Water absorption (\%) & 17.7 & 13.3 & 15.6 & 22.9 & 15.9 & 20.4 & 22.1 & 19.8 \\
\hline
\end{tabular}




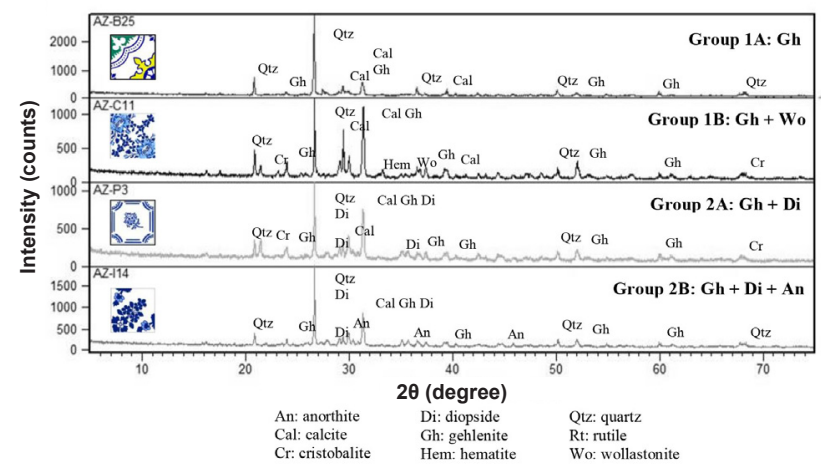

Figure 10: Identified minerals by X-ray diffraction in ceramic layer of the samples AZ.B25, AZ.C11, AZ.P3 and AZ.I14.

[Figura 10: Minerais identificados por difração de raios $X$ na cerâmica das amostras AZ.B25, AZ.C11, AZ.P3 e AZ.I14.]

and wollastonite (Group 1.B); 2) ceramics with minerals derived from $\mathrm{Ca}-\mathrm{Mg}$-rich clays, which included samples AZ.M18 and AZ.P3, with the presence of gehlenite and diopside (Group 2.A), and sample AZ.I14, which contained gehlenite, diopside and anorthite (Group 2.B) (Fig. 10).

\section{DISCUSSION}

\section{Physical and micromorphological characteristics}

Glazed layer: in the nineteenth century, tiles decorated by a stamping technique used to be thick. This thickness was due to the decoration process, which used a dual glazed layer, one for preparation (with tin oxide) and one for decoration (with chromophore oxides) [4]. That explains the large thickness observed in the vitrified layer of Soledade tiles. The manufacturing defects observed in the Soledade samples are common in this kind of tiles, mostly because of the semi-industrial process, which does not purify or treat the raw material to improve its properties. The defects can be formed by the retraction of the ceramic layer during firing, or by stresses generated by incrustations inside the material [4]. Therefore, the white glazes of the ancient tiles used to have big particles due to traces of raw materials that did not reach the fusion point during firing, but they can be also related to economic factors. The inclusions contribute to the opacification of the glaze and therefore decrease the amount of $\mathrm{SnO}_{2}$ necessary to cover the ceramic, which reduces the costs [5]. These factors explain the existence of big particles in the white glazes of Soledade tiles.

Ancient glazes generally have a complex chemical composition, mainly due to the inclusion of pigments and fluxes [6]. The base of the vitreous matrix is composed primarily of $\mathrm{PbO}$ and $\mathrm{SiO}_{2}$, with additions of other elements such as $\mathrm{CaO}$ and $\mathrm{K}_{2} \mathrm{O}$ used as fluxes, possibly in the form of a calcium carbonate and a K-feldspar [5, 7]. Tin predominates in the white glaze, used extensively in the Portuguese manufacture of majolica stamp and relief tiles from the seventeenth to the nineteenth centuries, because it guarantees the separation of chromophore oxides and the opacity of the glaze [6, 8-12]. For the decoration, the colors were obtained from metallic oxides, such as copper, cobalt, iron, manganese, or synthesized pigments, which were used alone or mixed with other pigments $[5,8,9,13]$. This kind of composition, with $\mathrm{PbO}$ and $\mathrm{SiO}_{2}$, $\mathrm{Sn}$, fluxes and pigments, was observed in Soledade tiles. Cobalt is responsible for the blue color of the analyzed patterns [5, 6, 9, 14]. Manganese identified in orange-brown and black shades of sample AZ.N33 is associated with antimony and iron to achieve the desired color $[5,8,9,11]$.

Ceramic layer: the production of Portuguese tiles in the nineteenth century, in general, still used rudimentary techniques and raw materials, which directly affected the quality of the product, such as its porosity $[15,16]$. The result of this production process is observed in the heterogeneity of the ceramic layer of Soledade tiles. The chemical composition identified in the ceramics matrixes in this study is characteristic of Portuguese tiles from this period [7]. The addition of materials to the paste, such as feldspars, phosphates, carbonates, sea salt and volcanic ash, was common in order to decrease the firing temperature [7]. So, elements such as sodium and potassium, present in Soledade ceramic samples, may have been added as fluxes. The percentage of $\mathrm{Fe}_{2} \mathrm{O}_{3}$ found in Soledade samples is responsible for the yellow color of the ceramic [7, 17]. The PbO concentrations in the ceramic of sample AZ.C11 probably came from a contamination of glaze components through the porosity of the material.

The content of silicon, calcium and magnesium in the Soledade samples indicates the use of clays rich in carbonates, or the addition of carbonates to raw material, which may be one of the causes for the presence of vacuoles in the glaze and voids in the ceramic, since these compounds decompose during firing and release $\mathrm{CO}_{2}$ [7]. These defects can even be caused by retraction fissures or presence of organic matter in the paste, which also release $\mathrm{CO}_{2}$ during firing [4]. The relation between the volume of voids and the total volume of the sample in the ceramic material, verified by the results of the absorption test, indicate an average porosity if compared with the results obtained in another study with 20 tiles produced in the sixteenth, seventeenth and nineteenth centuries showing variations from 9.32 to $42.30 \%$ [18]. There is a higher percentage of voids in samples AZ.B25, AZ.I14, AZ.18, AZ.N33, AZ.P3 and the opposite in samples AZ.C11, AZ.F11, AZ.H7, AZ.M5. This absorption capacity may also be associated with the presence of fissures in the material, because it is another water percolation path $[4,19]$. The porosity of the material has a strong influence on its physical and mechanical properties and durability, because the higher the porosity, the easier the ingress of water and other agents of deterioration [19].

Alterations: relations between defect and pathology are common since the methodology used in tile production can affect the final quality of the product [15]. The extent of cracking, present in some Soledade samples, can allow the entry and circulation of water inside the material, leading to weathering processes (physical, chemical and biological), 
as observed in the results (Fig. 9) [19]. This can create dark spots in the interface area between the layers, which results in the weakening of the adherence of the glaze to the ceramic, and consequently in the detachment of the glaze and disintegration and/or alteration of the ceramic material, facilitated by its high porosity [4].

\section{Mineralogical composition of ceramic layer}

In the results of the mineralogical characterization of ceramic parts, it was possible to observe the presence of minerals belonging to the raw material and formed by the firing because of mineral transformations that occur with increasing temperature [15,20-22]. The mineralogical variety of samples indicated that the raw material of the samples was composed primarily of quartz, calcite and/or dolomite, hematite or goethite, and clay minerals, such as kaolinite, common results for Portuguese samples from the nineteenth century [16]. The incidence of gehlenite, in all Soledade samples, formed at about $850 / 900{ }^{\circ} \mathrm{C}$ is an indication that the firing reached temperatures near or equal to $1000{ }^{\circ} \mathrm{C}$ [7]. Therefore, the presence of calcite in Soledade ceramic bodies, a mineral with melting point near $900{ }^{\circ} \mathrm{C}[16]$ and lower than firing temperatures, indicated that this equivalent mineral did not come from the raw material. Instead, it originates from the carbonation of calcium hydroxide, which probably migrated from mortar lime used for the laying of the tiles [7]. The same occurred with quartz, identified in all the Soledade samples. The firing temperature of the Soledade samples exceeded transformation temperature of quartz into tridymite $\left(870{ }^{\circ} \mathrm{C}\right)$. However, this equivalent mineral was not found in the Soledade samples due to the fact that tridymite is usually very rarely obtained and the temperature also trespasses its melting point.

The presence of quartz in all the Soledade ceramic samples and cristobalite in samples AZ.C11 and AZ.P3 is due to the fact that during the nineteenth century, with the development of the ceramic industry, it was common to mix quartz with clay in order to improve the mechanical properties of the ceramic material [22]. The cristobalite is a stable silicate, in general originated at temperatures between 1050 and $1250{ }^{\circ} \mathrm{C}$ by quartz transformation [16, 23]. Because of the low intensities of the peaks it is very likely that the firings did not reach $1400{ }^{\circ} \mathrm{C}$ to achieve the stable phases of this equivalent mineral. Another indication that the temperature was not reached is that mullite $\left(3 \mathrm{Al}_{2} \mathrm{O}_{3} .2 \mathrm{SiO}_{2}\right)$, which usually coexists with cristobalite when arising from transformations of kaolinite [16, 24], was not formed. The vast presence of carbonates may have contributed for cristobalite formation at lower temperatures. The incidence of these two contrasting structures (according to their fusion point) in the paste of samples AZ.C11 and AZ.P3 can be explained by temperature discontinuities inside the oven. Some mineral transformations can be incomplete and only occur at the grain boundaries [21]. It is also possible that the quartz was formed during the cooling of the tiles [16].

The major presence of minerals that carry calcium and/ or magnesium observed in the results of Soledade ceramic samples indicated that the clay used as raw material was rich in carbonates. During the firing of $\mathrm{Ca}-\mathrm{Mg}$-rich clays for ceramic production, the formation of a large number of mineral phases occurs [17]. In the formation of minerals, such as gehlenite, anorthite, wollastonite, found in the samples of Groups 1 and 2, the use of Ca-rich clays was verified, because these minerals originate from the reaction between silica and calcium compounds [14, 21, 25]. For the formation of gehlenite and anorthite, these reactions may occur from calcite and clay minerals such as kaolinite $\left[\mathrm{Al}_{2} \mathrm{Si}_{2} \mathrm{O}_{5}(\mathrm{OH})_{4}\right][16,21,26]$ or, in the case of anorthite, it can be derived from reactions of gehlenite with aluminum phases (metakaolin) and silica [26]. Regarding the formation of diopside, found in Group 2 samples, it is probable that $\mathrm{Ca}-\mathrm{Mg}$-rich clays were used, because this mineral originates from the reaction of silica with phases of calcium and magnesium [25], possibly from mineral transformations of calcite and dolomite $[16,27]$.

\section{CONCLUSIONS}

The historical tiles of Nossa Soledade Cemetery have great representation in relation to the heritage of northern Brazilian tiles. This characterization will contribute to future restorations in the Cemetery. The step of characterization is essential before starting a restorative intervention in a tile panel for 3 reasons: 1) although they all have the same country of origin (Portugal), century of production (nineteenth), decorative technique (stamping), and approximate firing temperature, the analyzed tiles present variations in their microstructural and mineralogical characteristics, probably because of the different raw materials used and variations in the temperatures inside the oven, both the result of rudimentary technologies; 2) due to these differences, the results obtained in the characterization of the pieces can influence the choice of techniques, processes and products of conservation and restoration to be used; and 3) the characterization also contributes to the production of tile replicas, regarding the quality of raw materials and firing temperature.

\section{ACKNOWLEDGEMENTS}

We are grateful to CAPES (Coordination for the Improvement of Higher Education Personnel) and $\mathrm{CNPq}$ (National Council for Scientific and Technological Development), for financial support and providing scholarships to the first author. We also thank IPHAN/ PA, FUMBEL and SEURB, for permission to work at the Soledade Cemetery; LabMEV and LCM, from the Geosciences Institute at UFPA, for the SEM/EDS and X-ray analysis.

\section{REFERENCES}

[1] D. Alcântara, in: Patrimônio azulejar brasileiro: 
aspectos históricos e de conservação, Org. M.C.V.L. Dias, Monumenta, BID, Min. Cultura (2001) 27.

[2] F. Queiroz, in: Actas Congr. Int. “Azulejar 2012”, Aveiro e Ovar (2012).

[3] Assoc. Bras. Nor. Técn., ABNT NBR 15845, "Rochas para revestimento - métodos de ensaio" (2010).

[4] T.A.B.C. Sanjad, "Intemperismo tropical em fachadas azulejadas de edificações históricas de Belém do Pará", Tese Dr., UFPA, Belém, PA (2007).

[5] S. Coentro, J.J. Mimoso, A.M. Lima, A.S. Silva, A.N. Pais, V.S.F. Muralha, J. Eur. Ceram. Soc. 32 (2012) 37.

[6] M.O. Figueiredo, J.P. Veiga, T.P. Silva, J.P. Mirão, S. Pascarelli, Nucl. Instr. Meth. Phys. Res. B 238 (2005) 134.

[7] M.L. Costa, T.A.B.C. Sanjad, R.S. Paiva, Acta Amazônica 43 (2013) 323.

[8] A. Guilherme, J. Coroado, J.M.F. dos Santos, L. Lühl, T. Wolff, B. Kanngießer, M.L. Carvalho, Spectrochim. Acta Part B 66 (2011) 297.

[9] M.S. Tite, J. Archaeol. Sci. 36 (2009) 2065.

[10] C. Lepierre, Estudo químico e tecnológico sobre a cerâmica portuguesa moderna, Impr. Nac., Lisboa (1899).

[11] M. Pereira, T. de Lacerda-Aroso, M.J.M. Gomes, A. Mata, L.C. Alves, P. Colomban, J. Nano Res. 8 (2009) 79.

[12] J.P. Veiga, M.O. Figueiredo, Appl. Phys. A 92 (2008) 229.

[13] R. Roldán, J. Coll, J. Ferrero, J. Cult. Herit. 7 (2006) 134.

[14] L.D. Koch, D. de Wall, Spectrochim. Acta Part A 71 (2008) 1348.

[15] G. Cultrone, F. Madkour, J. Cult. Herit. 14 (2013) 304.
[16] T. Sanjad, R. Angélica, M. Oliveira, M. da Costa, REM: Rev. Esc. Minas 57 (2004) 255.

[17] L. Nodari, E. Marcuz, L. Maritan, C. Mazzoli, U. Russo, J. Eur. Ceram. Soc. 27 (2007) 4665.

[18] T.A.B.C. Sanjad, "Patologias e conservação de azulejos: estudo tecnológico de conservação e restauração com azulejos dos séculos XVI, XVII e XIX pertencentes às cidades de Belém e Salvador", Diss. Mestr., UFBA, Salvador (2002).

[19] T.P. Santos, M.F. Vaz, M.L. Pinto, A.P. Carvalho, Constr. Build. Mater. 28 (2012) 104.

[20] G. Cultrone, E. Sebastin, K. Elert, M.J. Torre, O. Cazalla, C. Rodriguez-Navarro, J. Eur. Ceram. Soc. 24 (2004) 547.

[21] M.P. Riccardi, B. Messiga, P. Duminuco, Appl. Clay Sci. 15 (1999) 393.

[22] M.F. Vaz, J. Pires, A.P. Carvalho, J. Cult. Herit. 9 (2008) 269.

[23] A. Gualtieri, M. Bertolani, Appl. Clay Sci. 7 (1992) 251.

[24] F. Sahnoune, M. Chegaar, N. Saheb, P. Goeuriot, F. Valdivieso, Appl. Clay Sci. 38 (2007) 304.

[25] P. López-Arce, J. Garcia-Guinea, M. Gracia, J. Obis, Mater. Charact. 50 (2003) 59.

[26] K. Traoré, T.S. Kabré, P. Blanchart, Ceram. Int. 29 (2003) 377.

[27] A.P. Carvalho, M.F. Vaz, M.J. Samora, J. Pires, Mater. Sci. Forum 514-516 (2006) 1648.

(Rec. 20/04/2016, Rev. 21/09/2016, 23/03/2017, 13/04/2017, Ac. 14/05/2017) 